\title{
Revitalization and Adaptive Re-use in Cappadocia: A Taxonomy of Creative Design Solutions for Uçhisar Boutique Hotels
}

\author{
* Asst. Prof. Dr. Suzan Girginkaya Akdağ 1 (D), Phd. Stu. Berna Sayar 2 (i) \\ 1 and 2 Faculty of Architecture and Design, Bahçeşehir University, Istanbul, Turkey \\ ' Email: suzan.girginkayaakdag@arc.bau.edu.tr ,2Email: berna.sayar@arc.bau.edu.tr
}

\section{AR T I CLE I N F O: \\ Article history: \\ Received 20 June 2019 \\ Accepted 23 July 2019 \\ Available online 8 September \\ 2019}

\section{Keywords:}

Revitalization;

Adaptive Re-Use;

Sustainable Building;

Sustainable Tourism;

Creative Design;

Vernacular Architecture

$$
\begin{aligned}
& \text { This work is licensed under a } \\
& \text { Creative Commons Attribution - } \\
& \text { NonCommercial - NoDerivs 4.0. } \\
& \text { "CC-BY-NC-ND" } \\
& \text { This article is published with Open } \\
& \text { Access at www.ijcua.com }
\end{aligned}
$$

\begin{abstract}
A B S T R A C T
The "architecture without an architect" in Cappadocia has always been fairy due to its volcanic stone formations and transforming silhouettes. In 1973, French architect Jack Avizou highlighted the essence of cave houses as vernacular building types and their potentials for local tourism beyond conventional notions of architectural heritage. Upon completing the restoration of cave houses in Uçhisar and transforming them to boutique hotels, he was nominated for Aga Khan Award for Architecture in 2010. On the other hand, Aga Khan Award winner Turkish architect Turgut Cansever had also been advising for Argos Hotel project in Uçhisar since 1996. He gave importance to the concept of "protection" and preserved vernacular identity and characteristics despite the demands of the tourism sector. This paper aims to explore Avizou and Cansever's design solutions in Uçhisar's local context. Building / interior design elements and spatial relations in interiors will be analyzed with cluster analysis and ranked according to levels of novelty. Hence, achievement of creativity through transformation, combination and variation of original designs, will be displayed. Understanding Avizou's and Cansever's visions on revitalization and adaptive reuse are substantial since their creativity shall be a source of inspiration for future sustainable tourism and building practices in the local and global context.
\end{abstract}

Journal Of CONTEMPORARY URBAN AFFAIRS (2020), 4(2), 37-50.

https://doi.org/10.25034/ijcua.2020.v4n2-4

www.ijcua.com

Copyright (C) 2019 Journal of Contemporary Urban Affairs. All rights reserved.

\section{Introduction}

For economic growth, especially during times of financial crises, tourism is regarded as an accelerator. The UN World Tourism Organization (UNWTO) research demonstrated that interest in the environment, culture and heritage is a primary motivation for more than $50 \%$ of travel, and is consistently growing as a market sector (Brooks, 2012). According to the Council of Europe (Council Of Europe, 2005), cultural heritage is valuable in itself and for the 'contribution it can make to other policies'. Many countries have invested large sums in the restoration of various historical sites with the aim of maintaining jobs in the tourism sector and using cultural heritage as a tool to stimulate cultural and economic development in a period of economic recession (Inkei, 2011). Hence, the construction industry and small and medium-sized businesses are being preserved besides historic monuments and sites. Beyond the economy, cultural tourism has significant socio-cultural and environmental impacts on the host society.
*Corresponding Author:
Faculty of Architecture and Design, Bahçeşehir University, Istanbul, Turkey
Email address: suzan.girginkayaakdag@arc.bau.edu.tr 
During World Summit on Sustainable Development

(World Summit on Sustainable Development, 2002), it was stated that: "The contribution that tourism can make to poverty alleviation, to the conservation of the natural and cultural heritage, and overall sustainable development can be substantial. This is especially so in developing countries, where natural resources and landscapes are still relatively untouched and where few other activities have sustainable development potential, from an economic or environmental perspective. Furthermore, tourism has proved to be in many countries a much more sustainable development option than intensive agriculture, forestry, extractive mining or other primary activities".Thus, cities themselves have already become products within the economy of consumption. The identity of cities or areas has been redesigned, presented and consumed steadily. In global competition and mobility of tourism, field branding strategies are applied for increasing the cities' recognition, recalling their identities and main characteristics and developing new strategies for their consumption (Zhang and Zhao, 2009). Efficient city branding depends on the identification of the main characteristics of the city including its identity, historical, cultural activities, demographic characteristics, economy, perception of the city and experiences of people etc.

Hence, cultural heritage with its overall physical, diverse and intangible components require new strategies of preservation, renovation and adaption. For preserving cultural heritage, The Council Of Europe (1985) suggested the use of protected goods in the light of modern living needs; adaptation of old buildings for new purposes (when possible); and harmonization of the needs for protection with the needs of modern economic, social and cultural activities. As shown in Table 1, revitalization and adaptive re-use of heritage buildings and sites are rooted in a number of disciplines including economy, sustainable tourism, tourism marketing, city branding, preservation and sustainable building. The aim of this paper is to inspect sustainable design strategies applied in the revitalization of Cappadocia as a tourism centre. The case study will focus on adaptive re-use of cave houses as boutique hotels.

Table 1. Theories of Revitalization and Adaptive Re-use in Sustainable Tourism and Building (Developed by Authors)

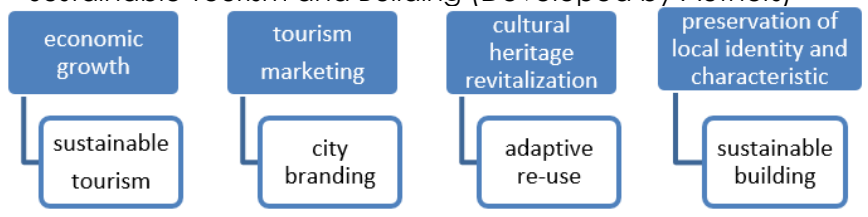

\subsection{Revitalization and Adaptive Re-use of Heritage Buildings and Sites}

In tourism, consumers' motivations and behaviours are increasingly characterized by a more selective choice of destination, greater attention to the tourism experience and its quality, a greater sensitivity to the environment, vernacular culture and local people at the destinations. Hence, cultural tourism and its sustainability are possible through the preservation of vernacular identity and characteristics. Applying determined place / urban identity in all areas of design (in a collective manner), is an advertising and marketing technique for place branding (Usal, 2011). Therefore, contemporary strategies and practices have been shaped around revitalization and adaptive use of heritage buildings and sites.

Vernacular architecture is a great source for architects, urban planners, and relevant service providers who are expected to develop sensitive scenarios to physical, economic, social and environmental needs. In vernacular architecture, physical characteristics of the region including the climate, tectonics and landscape blend with cultural and social values. Vernacular architecture, as a result of hundreds of years of experience, is efficient in meeting the needs of local environmental conditions and quality of life. Vernacular buildings require less energy for their construction, operation and maintenance thus, they are sensitive to nature and their environments.

In Turkey, several architects in their projects have successfully integrated vernacular design principles that determine the sustainable identity of vernacular architecture. The architect Turgut Cansever, who later advised for Argos Boutique Hotel in Cappadocia, was awarded three times with the international Aga Khan Award for his contributions to vernacular architecture along with urban and rural development policies. Cansever's projects Ahmet Ertegun House (1980), Turkish History Foundation Building (1980) and Demir Holiday Village (1992) were all found to be valuable for their sensitive approaches to economic and environmental problems. This paper includes samples from Cansever's design approach to Cappadocia as well as French architect Avizou, who was the first figure to emphasize the significance of vernacular architecture and highlight its potentials for tourism in the region. 


\section{Vernacular Architecture in Cappadocia}

Cappadocia; was shaped 60 million years ago with lava and ashes of Erciyes, Hasandağı and Güllüdağ mountains and erosion of these soft layers rain by the wind and rain during millions of years. Throughout history, many civilizations including Assyrian trade colonies, Hittites, Persians, Romans, Anatolian Seljuks, Karamanoğulları and Ottomans have settled on this land. Traditional Cappadocia settlements were independent of strict design rules. Cave settlements were formed in centuries as a result of natural and human forces by abrasion and friction. Caves provided various functions such as sheltering, worship, defence, burial place, storage and transition tunnels. Easy digging of shelters facilitated expansions and connections with new corridors and stairs on need. People developed their defence mechanisms skilfully upon discovering the suitability of caves for hiding and defending. Therefore, cave houses scattered on the sloping terrain, have become the characteristic pattern of Cappadocian architecture. They featured rational and creative solutions, which were shaped around principles of sustainability.

The streets in Cappadocia conformed to topographical features. They were usually scaled according to dimensions that allowed animals (carrying the human load) could pass. These organic streets were limited either by wood/stone cantilevered building masses, high garden or courtyard walls, depending on regional characteristics. Cappadocian settlements; could be classified into three categories including underground carved settlement, slope carved settlement and rock-carved settlement. Stea and Turan (1993) termed them as carved-out spaces (lithospace) and built-out spaces (terrapace) during their investigation on placemaking and developed a model for housing patterns in Cappadocia (Table 2).

Table 2. Housing Patterns in Cappadocia (adaptation from text by (Stea \& Turan, 1993)

\section{Cappadocia Housing}

Carved-out housing

- Negative space

- Subtractive

- Away from surface

- Provides a strong defense mechanism with its depth and camouflage
Stone was the main building material of the Cappadocia region, due to its volcanic land. It was soft and easily processed when it came out of the quarry, but after contact with air, it became hard and very durable for building. Local people, who used to live in rock-carved spaces at first, started applying fine stonework to architectural structures. The most glorious built-up Cappadocia houses began to emerge in the 19th century with post-Tanzimat influences. Houses began growing in size and decorations appeared on facades. Ornamented mouldings, cantilevers and doors/windows converted to sculptures, appeared as authentic works of this late period. The stone called "kepez" also contained different color shades. Its porous structure provided serious insulation against heat. Its abundance, easy processing and thermal insulation have made stone workmanship a traditional construction technique in Cappadocia. In its history, a guild of 700 masters practising in the region was noted (Arkitera, 2017). Natural stone (volcanic tuff) offered unlimited possibilities, especially in terms of architecture: from small to enormous scaled caves with a variety of curves, roughness and textures in walls. Everything was designed according to the user's lifestyle and daily actions. Types of housing varied from "carved", "semicarved-semi-masonry" and "masonry" (Ulusoy Binan, 1993). Main components of carved space were living spaces, kitchens, cellars, warehouses, tandoor houses, places of worship, barns and stables etc. In addition, water wells and ventilation chimneys were indispensable in the underground world. All of the rooms open to a "hayat" surrounded by high courtyard walls.

Cappadocia houses had not been of interest for many years and were faced with collapse and disappearance. However, with revival of tourism after 1970's, Cappadocia region started to gain importance. New functions such as hotels, pensions, restaurants, discotheques, cafes and shops etc. were given to renovated historical buildings and put into service for tourism. In 1982, The Ministry of Culture launched a rescue operation. In 1985, preservation of heritage rock was finally recognized as "World Heritage" by UNESCO (Figure 1). The vaults carved into the lava stones in these primitive settlements started to take place on touristic media and marketing mediums all over the world. 


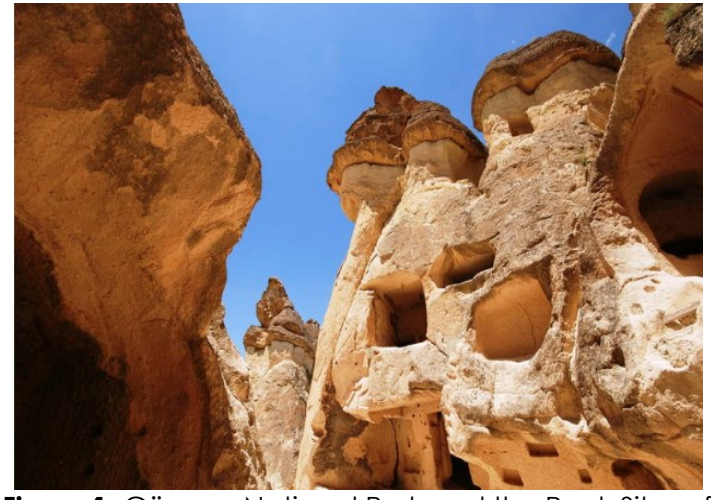

Figure 1. Göreme National Park and the Rock Sites of Cappadocia (Unesco, 2019).

\section{Revitalization and Adaptive Re-use of} Vernacular Houses for Tourism in Uçhisar

The best example of settlements, carved into rocks, is Uçhisar Castle and its surroundings. Uçhisar is the highest rock in the region. The horizon to be seen $90 \mathrm{~km}$ to the east, leads to the assumption that it was one of the attractive points preferred for asylum by the first Christians, who fled from the Romans. Turks moved to Anatolia in the $11^{\text {th }}$ century and preferred to settle in the old settlements. They also utilized Uçhisar as a protection and defence centre in Seljukid, Beyliks and Ottoman Periods (Cimşit, 2008).

As a neglected historical site, Uçhisar was identified as a disaster area in the 1960s and was abandoned with the support of the state. On leaving, many of the villagers removed stones from their original houses and used them to build their new houses. Hence, the village was ruined by the end of the 70s. On the other hand, ClubMed Hotel (1968-2005) opened and attracted international interest, mainly in French. Within time, Uçhisar has become a favourable destination for Belgium, Italian, American and Japanese tourists as well Turks from all over the country due to its suitable weather conditions between May and October. The development of similar infrastructures and services in Uçhisar has been boosting the tourism and related sectors in recent years (Figure 2).
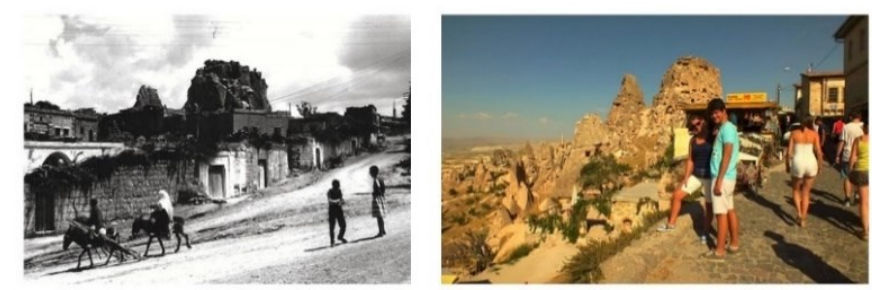

Figure 2. Revitalization of Uçhisar (Uchisar Municipality, 2019a).

Uçhisar is a defensive hill settlement. However, its stone and rock formation is problematic due to its softness, loose porosity and dune layers in between etc. Hence, structures in Uçhisar were built smaller compared to other regions with big cave monasteries. In addition to caves; additional rooms with flat roofs were built. They were built out of cutting stone on rock carvings. These rooms, owing to temperature and humidity regulations, had climatic advantages over caves (Figure 3).

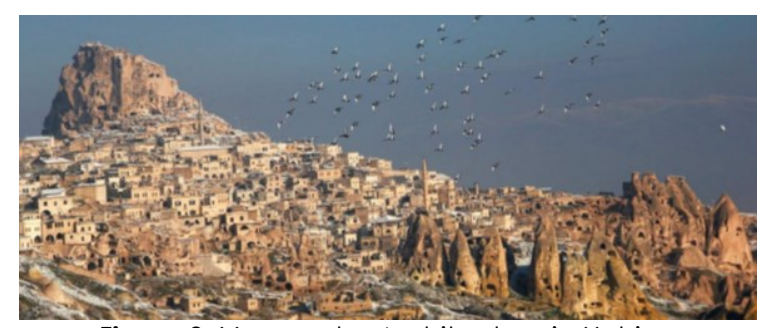

Figure 3. Vernacular Architecture in Uçhisar (Uchisar Municipality, 2019b).

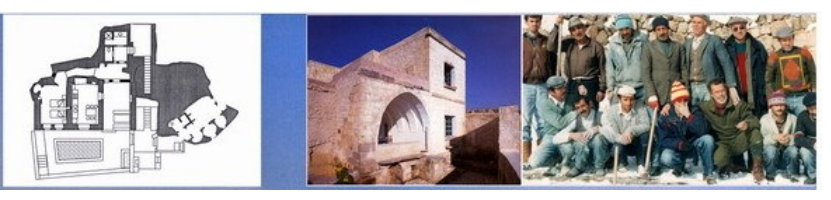

Figure 4. Restoration of Vernacular Housing by Avizou- for Les Maisons de Cappadoce (Archnet, 2019).

Due to poverty in Uçhisar, ground floor walls were built with more modest materials such as rubble / rough stones. Cut stone was only used at upper elevations. In Uçhisar houses; rooms were arranged around a common living area (inner courtyard). Decorations were sparse. Upper floor ceilings were covered with poplar structures called 'Hazen. The wood was scarce in ornamentation since the area was lacking trees. Wood was only used for doors in courtyards and interiors.

\subsection{Les Maisons de Cappadoce}

The adaptation of cave houses for contemporary use was initially introduced to Uçhisar by French architect Jack Avizou. Overwhelmed by the book called 'Architecture without Architects' (Rudofsky, 1964) and his touristic visits to Cappadocia, Avizou settled in Uçhisar in 1993. He set up a firm operating in the architecture and tourism sectors. He bought 17 cave houses abandoned by villagers and converted them into boutique hotels with a total of 31 rooms. Arvizu explained his efforts: 'Politicians were always discussing especially on the frescoes of the old chapels. I introduced the concept of heritage and restoration in this region' (Türkiye Gazetesi, 2009). According to Avizou's vision; bakery ovens, wine cellars, stairs carved into rocks, terraces and inner gardens started to appear in the middle of the isolated and striking Cappadocia landscape. He was inspired by vernacular art for decoration and used it in a simple style for authentic comfort. He designed interiors with pottery, rugs and carpets. He redesigned the local Turkish primitive human settlements according to French taste 
and later marketed them via his tourism company (Figure 4). The project was nominated for Aga Khan Award for Architecture in 2010 for its impetus throughout the region, due to the renovation of vernacular structures and revival of traditional crafts.

\subsection{Argos in Cappadocia}

Argos in Cappadocia is a restoration project of an old neighbourhood, which earlier was removed away stone by stone and became an excavation area in the 1970s. The founding partner of the Argos in Cappadocia hotel, Gökşin llıcalı, discovered Uçhisar in 1996 and decided to make a tourism investment through restoration. He hired Aga Khan awarded Turkish architect, Turgut Cansever for his master knowledge and former practices on vernacular architecture. During restoration, Cansever put emphasis was laid on vernacularity, respect for history and the importance of the place. The stone houses, which had been removed, were traced and spaces in between were designated according to the needs of the new function (Figure 5). The new layout, with original traces, was called as "içinden köy geçen hotel / the village with a reception desk" by Architect Özbay, the current coordinator of the project (URL 7).

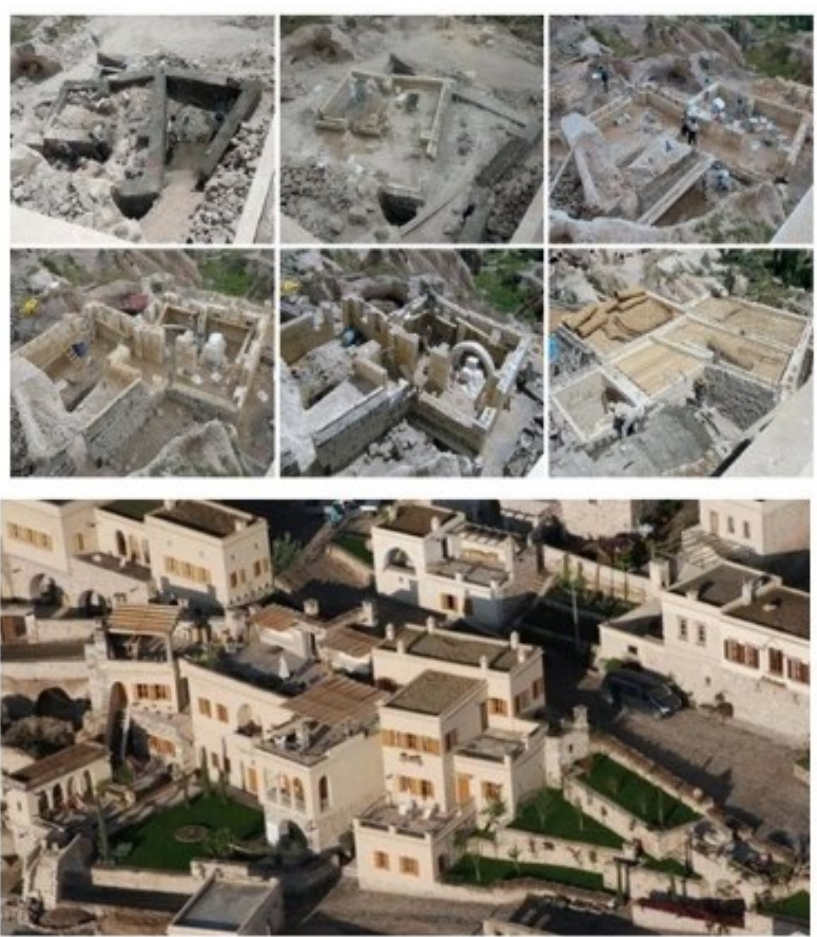

Figure 5. Restoration of Vernacular Housing Consulted by Cansever for Argos (Arkiv, 2019).

Keeping the new behind the original, respect for traditional textures and priority of local crafts, were effective strategies in the success of the final product. The project took a long time due to several stages. Masters of traditional crafts were seeking to train new craftsmen. The initial tourism company owning Argos was purchased in 2014 by a big Hotel Investments Group. With ongoing restoration work, Argos in Cappadocia has received several global and national awards (Table 3).

Table 3. Global and National Awards of Argos (Developed by Authors based on info

at Emlak kulisi [Real Estate Backstage], 2019).

- Excellence (Trip Advisor, 2010)

- World's Newest and Best 45 Hotels ( Travel+Leisure, 2010)

- "The most environmentally friendly projects in the world" (Conde Nast, 2010)

- "The Most romantic hotels in the world" /Conde Nast, 2011)

- 'Silver Magellan' at "The Most Luxury Hotel and Resort in the World" (Travel Weekly, 2011) "Boutique and Private Meeting Facilities" (1st Congress, Meeting and Event Awards - ACE of M.I.C.E, 2012)

- "Turkey's Best Boutique Hotel Investment" (Turkey's Most Successful Tourism Investment Survey, 2013)

- $\quad$ "Top 100 Hotels in the World " (Fodor's, 2014)

- "Best Hotels in the World" Categories (Travellers Choice, 2015)

- '5 Stars' at 'Best Hotel' and 'Sustainable Hotel' Categories (International Hotel Awards, 2015)

- 'Global First' at "The Most Beautiful Historic Luxury Hotel' Category (World Luxury Hotel Awards, 2016).

\section{Methodology and Case Study}

This paper focuses on the utilization of vernacular building / interior design elements for adaptive re-use of cave houses as boutique hotels. Case studies will include two awarded projects: Les Maisons de Cappadoce and Argos in Cappadocia (Table 4). First of all, images of selected elements will be classified with cluster analysis. Indeed, the concept of classification is noted as the building block for most of the cognitive capabilities human possess (Gagné, 1985). With classification, one can understand interrelationships of similar things together, based on a set of criteria or characteristics. Classification by architectural elements (Purini, 1968), allows categorization of large databases of building elements into semantic categories such as; certain historic periods, styles, cultural influences and functions 


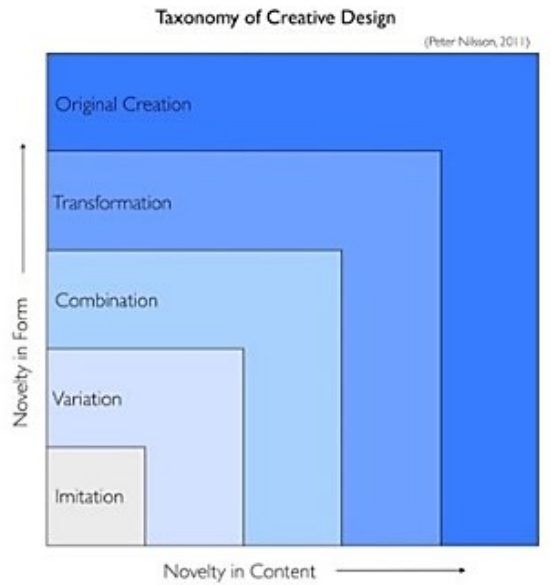

Figure 6. Taxonomy of Creative Design (Sense and Sensation, 2019).

After classification of building / interior design elements, their original and new uses will be compared according to levels of novelty. The model used in the study is 'taxonomy of creative design' by Nilsson (2011), which offers a progression from imitation to original creation (Figure 6). It helps to organize creative works into an inclusive, unifying landscape that serves as an analytical tool for evaluating creative work, and also as a methodical approach for developing creative skills. Today, Avizou's and Cansever's visions on adaptive re-use of cave houses are still inspiring current boutique hotel design projects. Therefore, this research intends to display the novelty of their design solutions and display their
Taxonomy of Creative Design ever Nasen 2011;

Imitation The replication of a previous work

Variation The modification of an existing work

Combination The mixture of two or more works

Transformation The translation of a work into another medium or mode

Original Creation The creation of something previously unrecognizable

Table 4. Adaptive Re-use Scenarios (Developed by Authors based on info at (Argos Yapi 2019).

\begin{tabular}{|c|c|c|c|}
\hline Property Name & Original Use & $\begin{array}{l}\text { New } \\
\text { Use }\end{array}$ & The benefit \\
\hline $\begin{array}{l}\text { Les Maisons de Cappadoce } \\
\text { (1994-2010) }\end{array}$ & $\begin{array}{l}\text { Cave house } \\
\text { Stables }\end{array}$ & Boutique Hotel & $\begin{array}{l}\text { Initialization of the concept of heritage and restoration in } \\
\text { Cappadocia }\end{array}$ \\
\hline $\begin{array}{l}\text { Argos Stage 1 } \\
\text { (1996-2002) } \\
\text { Mansion 'ManastırKonak' }\end{array}$ & $\begin{array}{l}\text { Monastery church from } \\
\text { 4th-5th century } \\
\text { Caravanserai or oil mill }\end{array}$ & Bezirhane & $\begin{array}{l}\text { Cultural and social events, (concerts, exhibitions and } \\
\text { theater performances, festive receptions, media } \\
\text { conferences, lectures, symposia, fashion shows etc. }\end{array}$ \\
\hline $\begin{array}{l}\text { Argos Stage } 2 \\
\text { (2001-2006) } \\
\text { Mansion } \\
\text { 'Tüneli Konak' }\end{array}$ & $\begin{array}{l}\text { Roman water tunnel with } \\
5.5 \mathrm{~km} \text { length }\end{array}$ & $\begin{array}{l}\text { Public } \\
\text { circulation } \\
\text { tunnel and } \\
\text { suite room }\end{array}$ & The first suite room with a pool inside \\
\hline $\begin{array}{l}\text { Argos Stage } 3 \\
\text { (2005-2009) } \\
\text { Mansion } \\
\text { 'Vasil Konak' }\end{array}$ & Residential & Boutique Hotel & $\begin{array}{l}\text { Open to public } \\
\text { Provides street-courtyard-panorama connections }\end{array}$ \\
\hline $\begin{array}{l}\text { Argos Stage } 4 \\
\text { (2007-2009) } \\
\text { Mansion } \\
\text { 'Gemil Konak' }\end{array}$ & Residential & Boutique Hotel & $\begin{array}{l}\text { Suite rooms with common facilities: restaurant, kitchen, } \\
\text { bar, lounge / lobby. }\end{array}$ \\
\hline $\begin{array}{l}\text { Argos Stage } 5 \\
\text { (2010-2011) } \\
\text { Mansion } \\
\text { 'White Konak' }\end{array}$ & Residential & Boutique Hotel & Suite rooms \\
\hline $\begin{array}{l}\text { Argos Stage } 6 \\
\text { (2012-2013) } \\
\text { Mansion } \\
\text { 'Tiraz Konak' }\end{array}$ & Residential & Boutique Hotel & Suite rooms \\
\hline $\begin{array}{l}\text { Argos Stage } 7 \\
(2014-16) \\
\text { Mansion } \\
\text { 'Kavak Konak' }\end{array}$ & Residential & Boutique Hotel & $\begin{array}{l}\text { Suite room with } \\
\text { "şrahane" (traditional kitchen) and "peynir odası" (cold } \\
\text { storage) }\end{array}$ \\
\hline $\begin{array}{l}\text { Argos Stage } 8 \\
\text { (2015-2017) } \\
\text { Personnel Building } \\
\end{array}$ & Residential & $\begin{array}{l}\text { Personnel } \\
\text { Building }\end{array}$ & $\begin{array}{l}\text { A large cafeteria and kitchen in basement, and dressing } \\
\text { and relaxation rooms on upper floors for hotel staff }\end{array}$ \\
\hline $\begin{array}{l}\text { Argos Stage } 9 \\
\text { (2015-2017) } \\
\text { Museum Saloon }\end{array}$ & $\begin{array}{l}\text { Caravanserai or oil mill } \\
\text { Staples }\end{array}$ & $\begin{array}{l}\text { Multi-use hall } \\
\text { Boutique Hotel }\end{array}$ & Exhibition of historic mill beds and mule circulation \\
\hline $\begin{array}{l}\text { Ladies' house } \\
\text { (2015-2015) }\end{array}$ & $\begin{array}{l}\text { Two heritage school } \\
\text { buildings from Republican } \\
\text { Period }\end{array}$ & $\begin{array}{l}\text { A restaurant } \\
\text { and shop for } \\
\text { jewelry and } \\
\text { food products }\end{array}$ & Handmade by Uçhisar ladies. \\
\hline
\end{tabular}


Following tables $5,6,7,8$ and 9 are taxonomies of adaptive re-use design guidelines according to levels of novelty in 'Fitting to Topography, Spatial stonemasons and carpenters, enabled preservation of local craft skills in the region. Many skillful architects, interior

Table 5. Taxonomy of Design Guideline 'Fitting to Topography' according to Levels of Novelty. Jction (Les Masion Cappadocia., 2019), (Argos Yapi 2019))

\begin{tabular}{|l|l|l|l|}
\hline \multicolumn{1}{|c|}{$\begin{array}{c}\text { Original Architectural / Interior } \\
\text { Design }\end{array}$} & \multicolumn{1}{c|}{$\begin{array}{c}\text { Transformation/ Combination/ } \\
\text { Variation }\end{array}$} & Imitation \\
\hline $\begin{array}{l}\text { Les Maisons de Cappadoce by Avizou } \\
\text { topography }\end{array}$ & Building types \\
\hline Argos in Cappadocia consulted by Cansever & $\begin{array}{l}\text { Vertical } \\
\text { circulation } \\
\text { elements } \\
\text { (staircases, } \\
\text { ramps, etc.) }\end{array}$ & $\begin{array}{l}\text { Building types } \\
\text { topography }\end{array}$ & $\begin{array}{l}\text { Vertical } \\
\text { circulation } \\
\text { elements } \\
\text { (staircases, ramps, } \\
\text { etc.) }\end{array}$ \\
\hline
\end{tabular}

Layout, Vernacular Construction Technics and sites.

Material, Interior Furnishing and Ethnographic Elements'.

Table 5, displays designers' levels of novelty in designing 'Fitting to Topography' criteria.

- Avizou's project Les Maison Cappadoce, is located on the outskirts of Uçhisar. Due to its location, exterior space use is focused on small gardens and balconies. On the other hand, Argos in Cappadocia, consulted by Cansever, is located on steep hills. Hence, terrace use is varying according to different functions: cafes, restaurants, cultivation activities.

- In both projects, emphasis was laid on the use of local materials and building techniques. For local people, new job opportunities were created in the building sector. The employment of local

Therefore, both projects have made remarkable contributions to sustainable economic growth. Additionally, young architects and interns were accepted to practice in Argo's restoration works. Besides support for architectural education, new and original knowledge was introduced to architectural history and theory through findings on heritage sites.

- The stairs in inner courtyards are out of local materials. Facade openings and entrances under stairs provide the relationship between middle courtyards and surrounding living spaces. The original function of courtyards for circulation has been preserved. 
Table 6. Taxonomy of Design Guideline 'Spatial Layout' according to Levels of Novelty.

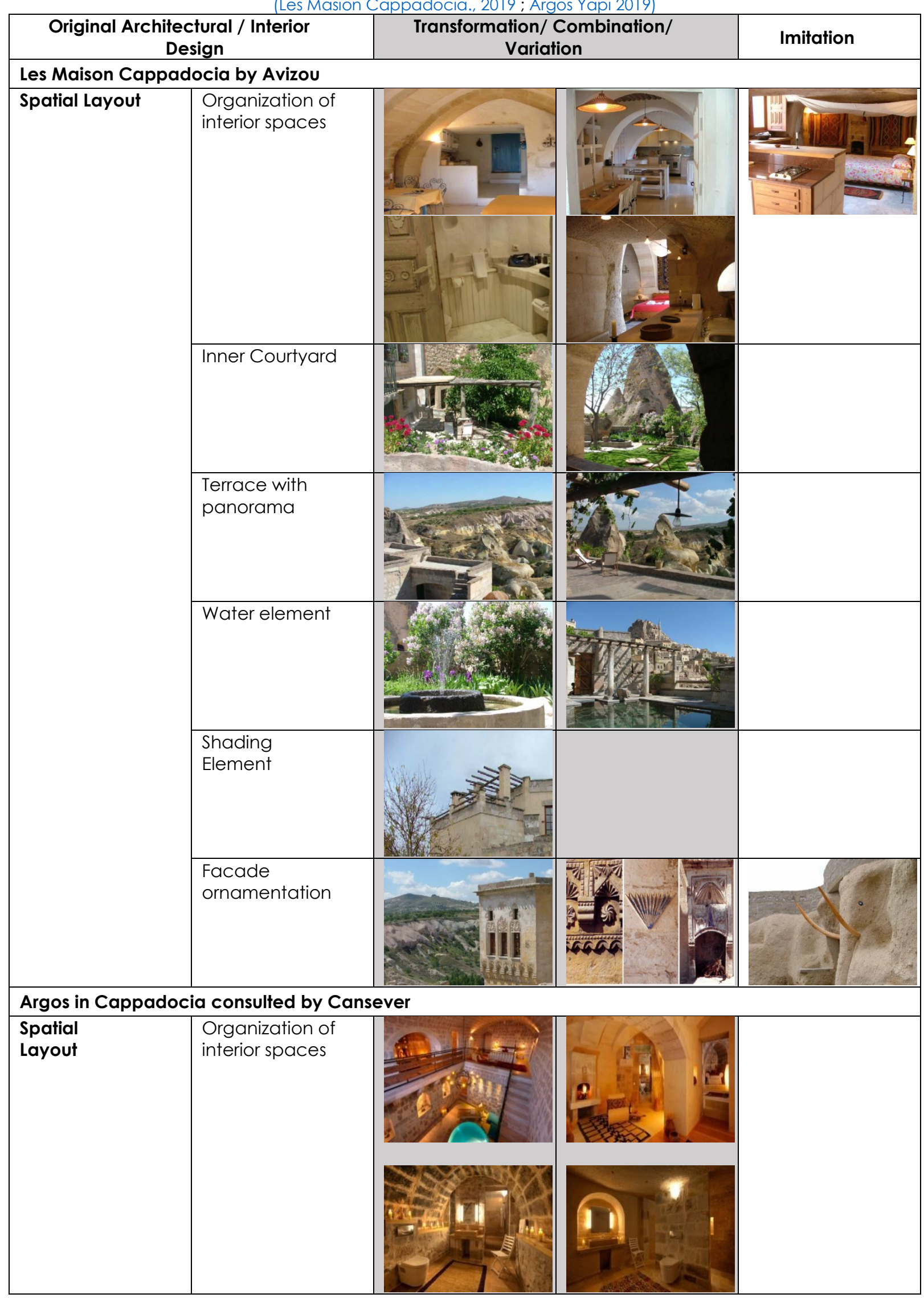




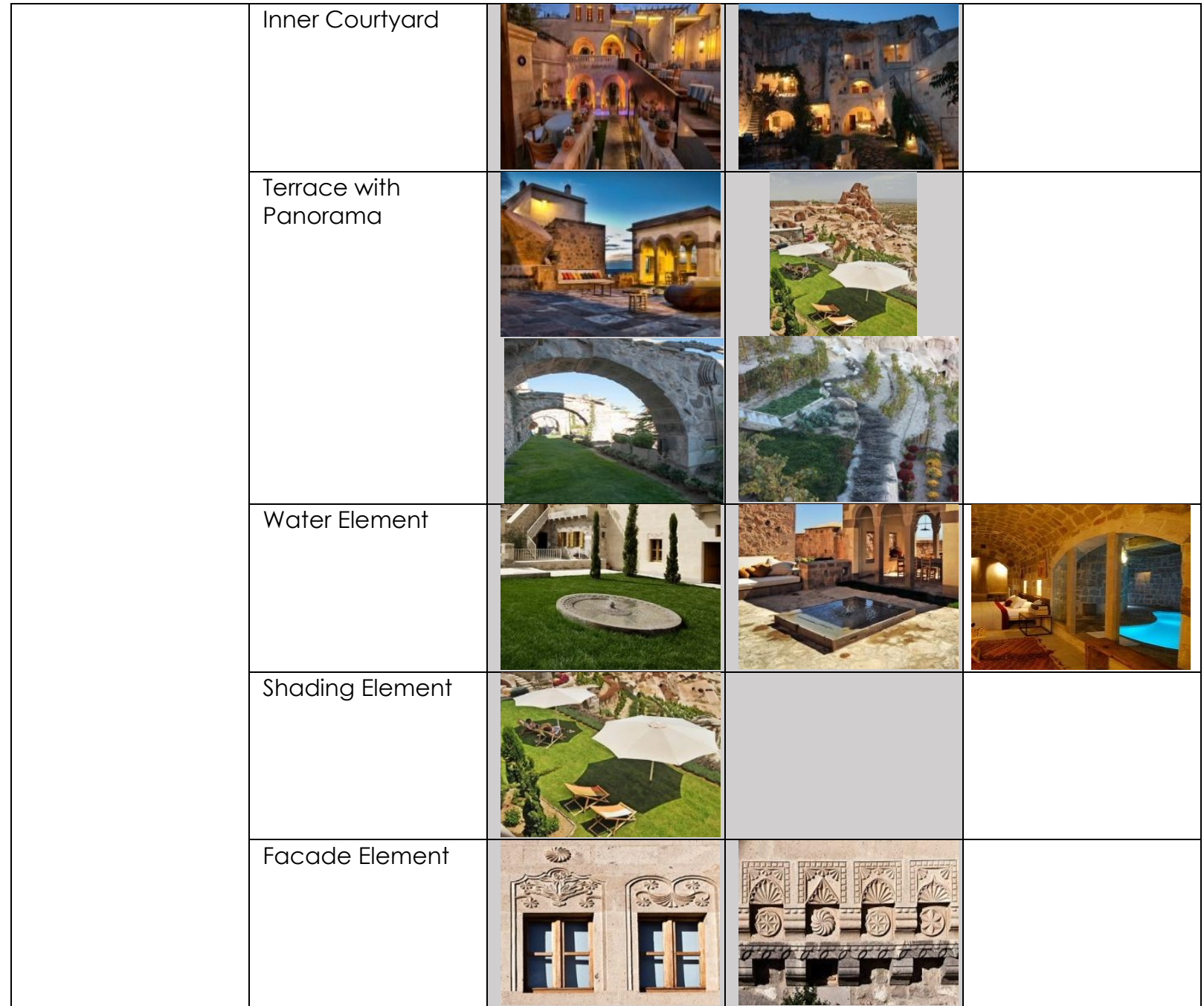


Table 6, displays designers' levels of novelty in designing 'Spatial Layout' criteria.

- In both projects, according to adaptive re-use for boutique hotels; spatial organizations were modified. In Les Maison Cappadoce, Avizou preserved the spatial integrity of houses with inner platforms and flow of volumes in between rooms. When new divisions were required, he proposed furniture islands or groupings. However in Argos, in line with luxury suite room concept, houses were divided into smaller parts. Original volumetric transitions were lost in most room designs.

- In traditional Cappadocia houses, inner courtyards were paved with stones. Originally, they were the service places, where food was prepared and cooked, routines such as laundry was done in daytime and where people cooled themselves down during hot summer nights. In both adaptive re-use projects, inner courtyards are covered with greenery for recreation and cafe restaurant facilities in line with tourists' interests. panorama viewing. They are furnished with seating groups directed towards panorama. In Les Maisons de Cappadoce, terraces are mostly left as stone pavement. In both projects, decorative water elements and small size stone pools with ornamental carvings, are placed in terraces and inner courtyards.

- In the terraces of Argos, the tradition of viniculture has been revitalized as a part of gourmet tourism. Arranged in platforms, several terraces have been planted with fruit trees and organic vegetables. Serving local wines in its cafes and restaurants, Argos in Cappadocia was chosen to be one of the best wine resorts in the world. This helped the revival of the cultivation culture and economy of these fertile lands. Currently, local wine producers export their high-quality wines to local and global markets. Several wine tasting and selling shops, which create new job opportunities for local people, have been opened.

- In both projects, during restoration practices, original stone relief motifs were preserved on building facades.

- In Argos, most stone covered terraces have been transformed to green terraces for

Table 7. Taxonomy of Design Guideline 'Vernacular Construction Technics and Materials' according to Levels of Novelty. (Argos Yapi 2019; Les Masion Cappadocia., 2019)

\begin{tabular}{|c|c|c|c|}
\hline Original Arc & $\begin{array}{l}\text { lural / Interior } \\
\text { ign }\end{array}$ & $\begin{array}{c}\text { Transformation/ Combination/ } \\
\text { Variation }\end{array}$ & Imitation \\
\hline Les Maisons de & oadoce by Avizou & & \\
\hline $\begin{array}{l}\text { Vernacular } \\
\text { Construction }\end{array}$ & $\begin{array}{l}\text { Wall types \& } \\
\text { coverings }\end{array}$ & & \\
\hline & $\begin{array}{l}\text { Facade openings } \\
\text { (Doorways \& } \\
\text { windows) }\end{array}$ & & \\
\hline & Ceiling structures & & \\
\hline Argos in Capp & a consulted by Car & & \\
\hline $\begin{array}{l}\text { Vernacular } \\
\text { Construction } \\
\text { Technics } \\
\text { and Materials }\end{array}$ & $\begin{array}{l}\text { Wall Types \& } \\
\text { Coverings }\end{array}$ & & \\
\hline
\end{tabular}




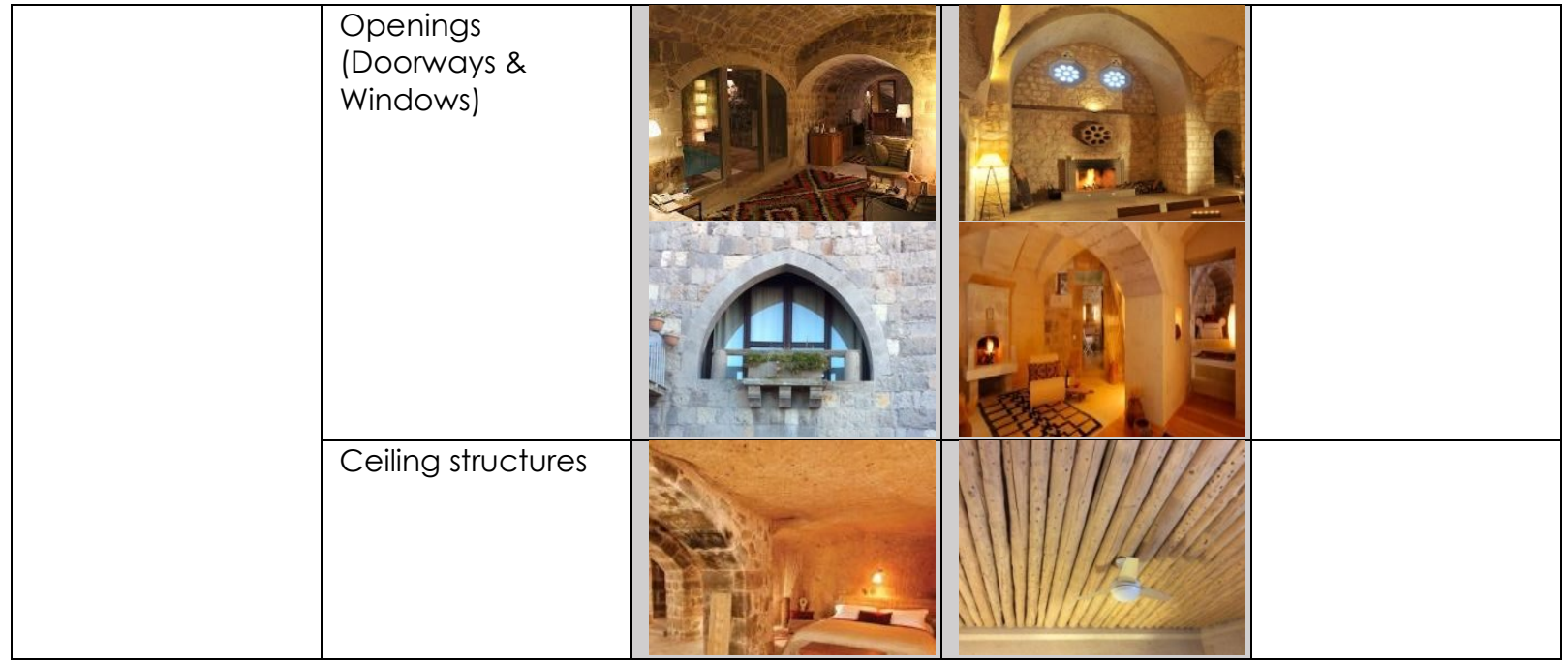

Table 7, displays levels of novelty in 'Vernacular Construction Technics and Materials' criteria.

- In both projects, original stone arches and wooden-beamed ceilings in rooms have been preserved. Additionally, rooms have been supported with ribbed vaults on locations where the rock is humid and non-durable.
- In bathrooms, travertine is preferred instead of tiles or ceramics. Argos in Cappadocia has some indoor pools (in few suites), which did not exist in vernacular architecture. These pools cause moisture and odor inside the rooms due to inadequate ventilation

Table 8. Taxonomy of Design Guideline 'Interior Furnishing' according to Levels of Novelty. (Les Masion Cappadocia., 2019), (Argos Yapi 2019))

\begin{tabular}{|c|c|c|c|}
\hline \multicolumn{2}{|c|}{$\begin{array}{c}\text { Original Architectural / Interior } \\
\text { Design }\end{array}$} & $\begin{array}{c}\text { Transformation/ Combination/ } \\
\text { Variation }\end{array}$ & \multirow[t]{2}{*}{ Imitation } \\
\hline \multicolumn{3}{|c|}{ Les Maison Cappadocia by Avizou } & \\
\hline \multirow[t]{6}{*}{$\begin{array}{l}\text { Interior } \\
\text { furnishing }\end{array}$} & $\begin{array}{l}\text { Level } \\
\text { difference }\end{array}$ & & \\
\hline & $\begin{array}{l}\text { Niches for } \\
\text { display }\end{array}$ & & \\
\hline & Wood furniture & & \\
\hline & Stone furniture & & \\
\hline & Seating inside & & \\
\hline & Fire place & & \\
\hline
\end{tabular}




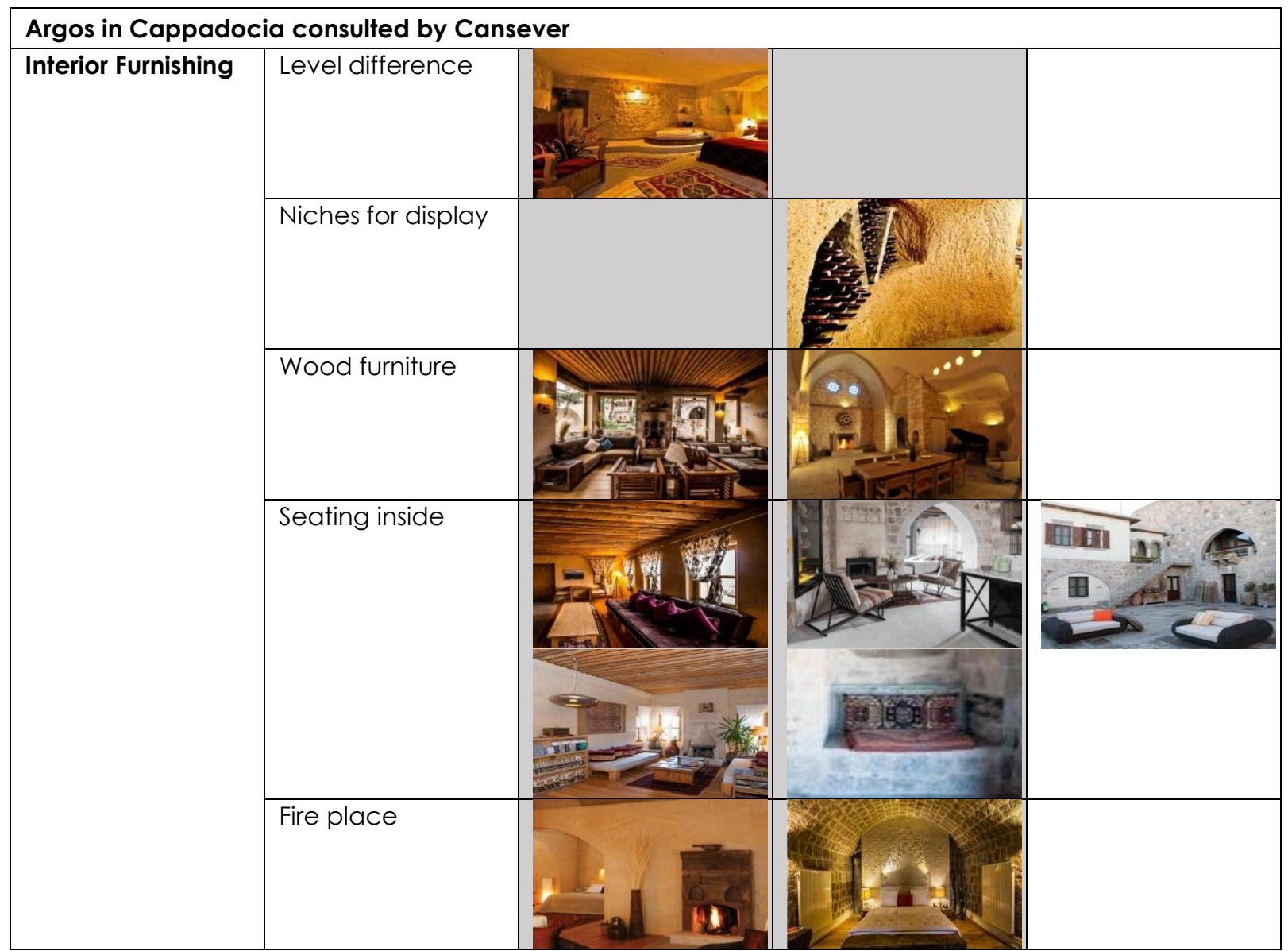

Table 8, displays designers' levels of novelty in designing 'Interior Furnishing' criteria.

- In both adaptive re-use projects, room interiors are furnished in a simple style. Modern furnishing is combined in harmony with local furniture, made out of cedar.

- Niches in interiors are used according to their original functions as display and storage areas.
- $\quad$ Fireplaces, which in the past were used for heating interiors, have been preserved in their original forms. Due to the provision of modern central heating systems, most fireplaces have simply become decorative elements. Only few can still be used upon request of hotel guests. 
Table 9. Taxonomy of Design Guideline 'Ethnographia' according to Levels of Novelty.

(Les Masion Cappadocia., 2019), (Argos Yapi 2019))

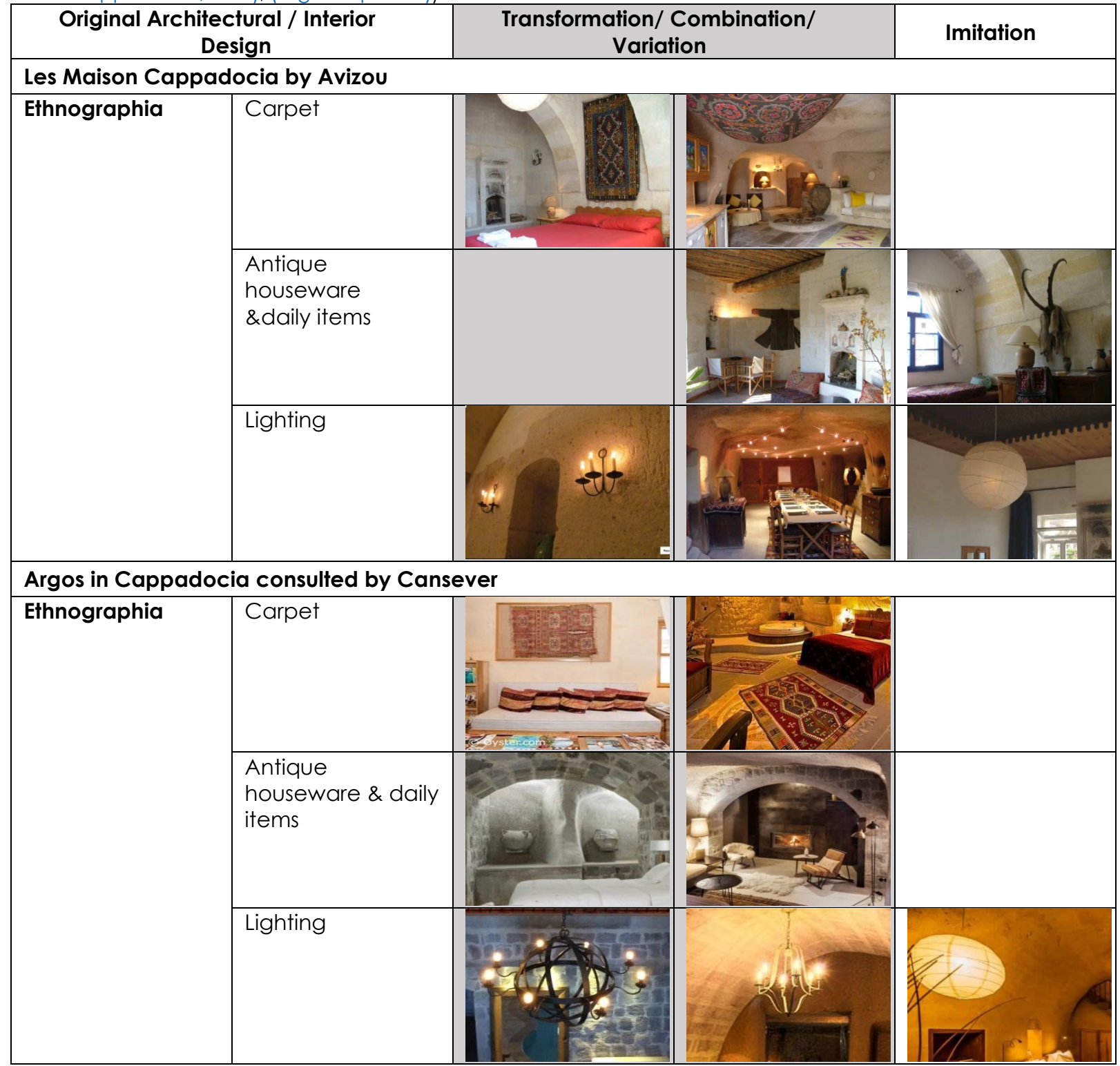

Table 9, displays designers' level of novelty in 'Ethnographia' criteria.

- In Les Maison Cappadoce, Avizou maintained the use of ceramic pots in daily functions. In Argos, original ceramic pots are being exhibited in wall niches as if in a museum.

- Traditional weaving rugs, which were used to cover stone floors in the past, are being exhibited on the walls, over beds and sofas as decorative elements.

- Interiors are lighted mostly by wall mounted chandelier or hidden lighting fixtures. In general, interiors are dimmed to preserve the cave ambience.

\section{Conclusion}

The two adaptive reuse projects introduced in this paper, display creative design solutions while preserving the vernacular identity and characteristics. Classification of spatial elements and relations helped further analysis of both projects according to levels of novelty that range from original and imitation. Within this taxonomy, the two architects' design solutions mostly revealed transformation, combination and variation of vernacular design guidelines such as: 'fitting to topography, spatial layout, vernacular construction technics and material, interior furnishing and ethnographic elements'. The respect for originality has dominated both projects. They displayed few imitated design solutions, which may have been added later by other decision-makers than the master architects themselves.

It is also important to highlight the coherency of sustainable building solutions between implementation phases and after-use scenarios of both projects. The use of local material and 
craftsmanship, training of stonemasons, carpenters and other construction workers, engagement of young architects and intern students in the building and restoration process has provided many job opportunities in the poor village of Uçhisar. The economic development, which initiated with construction work, has been further sustained through the business model of boutique hotels. Vernacular lifestyle has also been marketed according to the requirements of the tourism sector. Alternative experience-based activities have been proposed such as; tasting wine in platform terraces, eating and drinking in cafes and restaurants of Argos, walking tours in between fairy chimneys under the moonlight, meeting opportunities in the restored oil mill 'Bezirhane', entertaining in music, well-being and gourmet themed festival Cappadox, and shopping handmade local products. With an increasing number of such creative design solutions, which have all been inspired by vernacular architecture, revitalization and adaptive reuse in Cappadocia has generated a sustainable business model embracing local economy, tourism and building sectors.

\section{Acknowledgement}

This research did not receive any specific grant from funding agencies in the public, commercial, or not-for-profit sectors.

\section{Conflict of interests}

The authors declare no conflict of interest.

\section{References}

Archnet. (2019). Cappadocia Houses. https://archnet.org/sites/1295/media_contents/479 14

Argos Yapi (2019). "argos in Cappadocia" Hotel. http://www.argosyapi.com/TR/?p=Projeler

Arkitera. (2017). Taş, Buranın Yaşamına Dair Birçok Anlamı Içeren Bir Malzeme [Stone, A Material That Contains Many Meanings About The Life of This

https://www.arkitera.com/soylesi/neredePlace]. oldugunuzu-bilmiyorsunuz-burasi-gizemli-veopak-bir-dunya/

Arkiv. (2019). Argos in Cappadocia. http://www.arkiv.com.tr/proje/argos-incappadocia1/4605

Brooks, G. (2012). Heritage as a driver for development: Its contribution to sustainable tourism in contemporary society. ICOMOS, Paris, 496-505. http://openarchive.icomos.org/id/eprint/1207/1/III -1-Article1_Brooks.pdf
Cimşit, F. (2008). Tepe Kent Yerleşmelerinde Psiko-sosyal Alan Olgusunun Konut Örüntüleri Ile Ilişkisi; Uçhisar Örneği [The Relationship between the Psycho-Social Area and the Housing Patterns in the Hill Settlements; Uçhisar Example] İstanbul Technical University]. İstanbul. https://polen.itu.edu.tr/xmlui/handle/11527/6350?1 ocale-attribute $=$ en

Council Of Europe. (1985). Convention for the Protection of the Architectural Heritage of Europe. Granada, 3. https://rm.coe.int/168007a087

Council Of Europe. (2005). Convention on the Value of Cultural Heritage for Society(Faro Convention). https://rm.coe.int/1680083746

Emlak kulisi [Real Estate Backstage]. (2019). Argos in Cappadocia Awards. https://emlakkulisi.com/guncel/argos-incappadocia-odul/832737

Gagné, R. M. (1985). Conditions of learning and theory of instruction. Holt, Rinehart and Winston.

Inkei, P. (2011). Results of a 2011 Survey with Governments on Culture Budgets and the Financial Crisis and Culture, Directorate of Culture and Cultural and Natural Heritage, Steering Committee for Culture, Council of Europe. https://www.coe.int/en/web/culture-andheritage/culture

Les Masion Cappadocia. https://www.cappadoce.com/

Nilsson, P. (2011, 2011). The Challenge of Innovation. In Critical Thinking and Creativity: Learning Outside the Box the 9th International Conference of the Bilkent University, Turkey. http://www.senseandsensation.com/

Purini, F. (1968). Study of Architectural Elements. http://socks-studio.com/2014/10/12/franco-purinistudy-of-architectural-elements-1968/

Rudofsky, B. (1964). Architecture Without Architects: A Short Introduction to Non-pedigreed Architecture. University of New Mexico Press.

Sense and Sensation. (2019). Taxonomy of Creative Design. http://www.senseandsensation.com/2012/03/taxon omy-of-creative-design.html

Stea, D., \& Turan, M. (1993). Placemaking: Production of built environment in two cultures (Vol. 8). Avebury.

Türkiye Gazetesi. (2009). Altı şehir, üstü peri bacası [Underground city, overground fairy chimney]. https://www.turkiyegazetesi.com.tr/Genel/a40716 9.aspx 
Uchisar Municipality. (2019a). Uchisar in History. http://www.uchisar.bel.tr/uchisar/eski-uchisar/

Uchisar Municipality. (2019b). Uchisar Photo Gallery. http://www.uchisar.bel.tr/turizm/kapadokya/

Ulusoy Binan, D. (1993). Güzelyurt örneğinde, Kapadokya Bölgesi yı̆̆ma taş konut mimarisinin korunması için bir yöntem araştırması [A Research Method for Conservation of Masonry Stone Housing Architecture in the Cappadocia Region in Güzelyurt Case] Yıldız Technical University]. İstanbul. https://tez.yok.gov.tr/UlusalTezMerkezi/

Unesco. (2019). Göreme National Park and the Rock Sites of Cappadocia https://whc.unesco.org/en/list/357
Ürünlerinin Yeri-Kapadokya Iç̧in Bir Deneme [The Place of Leisure Design Products in Destination Branding: An Essay for Cappadocia] 1. Uluslarası Nevşehir Tarih ve Kültür Sempozyumu Bildirileri [1st International Nevşehir History and Culture Symposium Proceedings],

Nevşehir. https://dosyalar.nevsehir.edu.tr/dc70ae3653f4029 7749a34079d65d442/1_uluslararasi_nevsehirtarih _ve_kultur_sempozyumu-7.pdf

World Summit on Sustainabl Development. Presentation "Tourism and Poverty Alleviation". http://sdt.unwto.org/content/world-summitsustainable-development-wssd-johannesburg2002

Usal, S. S. Y. (2011, November 16-19). Alan Markalaşmasinda Boş Zaman Tasarim

Check for

Updates

How to Cite this Article:

Akdağ, S. G and Sayar B., (2020). Revitalization and Adaptive Re-use in Cappadocia: A Taxonomy of Creative Design Solutions for Uçhisar Boutique

Hotels. Journal of Contemporary Urban Affairs, 4(2), 37-50. https://doi.org/10.25034/ijcua.2020.v4n2-4 